\title{
Therapeutic Drug Monitoring and Population Pharmacokinetics of Digoxin in Jordanian Patients
}

\author{
Ehab Shaker ${ }^{1}$, Salim Hamadi ${ }^{1}$, Nasir Idkaidek ${ }^{1, *}$, Graham E Blakey $^{2}$, Akram Al-Saleh ${ }^{3}$ \\ ${ }^{1}$ Pharmacy College, Petra University, Amman, Jordan \\ ${ }^{2}$ GBPK Consulting Ltd, Nottingham, UK \\ ${ }^{3}$ Cardiology department, Jordan University Hospital, Amman, Jordan \\ *Corresponding author: nidkaidek@uop.edu.jo
}

Received January 27, 2013; Revised February 24, 2013; Accepted April 01, 2013

\begin{abstract}
Therapeutic monitoring of digoxin and the population pharmacokinetic parameters in Jordanian patients were done. Fifty three patients visited cardiac department of Jordan University hospital participated in this study, thirty two patients had congestive heart failure (CHF), while twenty one patients had atrial fibrillation (AF). Ninety three blood samples were collected from those patients for the measurement of digoxin level using AxSYM digoxin II assay method. Serum creatinine and potassium levels were also measured, in addition to blood pressure and heart rate. Microsoft Excel and Statistica programs were used for kinetic and statistical analysis. NONMEM computer program ADVAN 4 and 2 compartment model was used for population analysis of digoxin parameters. The serum digoxin level ranged from $0.11-4 \mathrm{ng} / \mathrm{ml}$. The percentage of all patients enrolled in this study that were out of therapeutic range was $49.05 \%$. Serum digoxin levels were out of therapeutic range in $53.12 \%$ of patients with CHF and $42.85 \%$ in those with AF. The pharmacokinetic parameters for digoxin obtained in this study using traditional methods were: creatinine clearance CLcr $(89.78 \pm 45.61 \mathrm{ml} / \mathrm{min})$, digoxin actual clearance CL $(200.57 \pm 154.52$ $\mathrm{L} /$ day $)$, volume of distribution $\mathrm{V}(541.57 \pm 149.87 \mathrm{~L}), \mathrm{t} 1 / 2(2.98 \pm 2.05$ day $)$, elimination rate constant $(0.41 \pm 0.396$ day $\left.^{-1}\right)$. A strong correlation was also found between actual digoxin clearance with $\log$ dose normalized $\left(\mathrm{R}^{2}=0.999\right)$, and $t 1 / 2\left(R^{2}=0.875\right)$. No correlations were found between the log of the normalized dose and other pharmacokinetic parameters or potassium levels. The population pharmacokinetic parameter for digoxin obtained in this study were: $\mathrm{CL}(3.34 \mathrm{~L} / \mathrm{h}), \mathrm{Vc}(3.27 \mathrm{~L}), \mathrm{Vt}(123 \mathrm{~L})$, inter-compartment clearance Q $(72 \mathrm{~L} / \mathrm{h})$, absorption rate constant KA $\left(1.25 \mathrm{~h}^{-1}\right)$. In Jordanian patients with either AF or CHF digoxin dose adjustment based on therapeutic drug monitoring principles is recommended. Digoxin pharmacokinetics were similar to those reported in non-Jordanian patients; estimated population pharmacokinetic parameters were in agreement with literature values.
\end{abstract}

Keywords: digoxin, population pharmacokinetics, TDM, NONMEM

\section{Introduction}

Digoxin is a heteroglycoside that is widely used for the treatment of congestive heart failure (CHF) and atria1 fibrillation (AF) for more than 200 years $[1,2,3]$. Therapeutic drug monitoring (TDM) for digoxin was started more than 30 years ago, and resulted in a marked reduction in the incidence of digoxin toxicity $[4,5]$. Serum digoxin monitoring is a suitable guideline for optimization of digoxin therapy since the drug has a narrow therapeutic index and large individual pharmacokinetic variability. The main indications for digoxin TDM include monitoring toxicity, assessing patient compliance, assessing the reasons for therapeutic failure, and assessing the effects of factors that alter the pharmacokinetic of digoxin (mainly renal dysfunction \& drug interactions) $[6,7,8]$. However, several studies reported that digoxin TDM is frequently performed inappropriately that limits its benefits \& increases unnecessary costs $[7,9,10,11]$. Therefore three criteria for proper use of digoxin TDM were suggested including proper indications, proper sampling time and proper interpretation of the measured digoxin level [1217]. Several population pharmacokinetic of digoxin studies were reported that estimate the pharmacokinetic parameters of digoxin to be used in clinical practice for estimating appropriate dosage regimen $[18,19,20,21,22]$. To date, no study on Jordanian patients has been completed investigating digoxin therapeutic drug monitoring and population pharmacokinetics. This study aims to investigate the appropriateness of digoxin drug therapy using TDM in a Jordanian population. Reasons for non-therapeutic outcomes will be explored.

\section{Patients and Methods}

\subsection{Patients}

The study population consisted of fifty three patients with $\mathrm{CHF}$ or $\mathrm{AF}$ and comprised $55 \%$ and $45 \%$ female and male white patients respectively. Age ranged from 33 to 85 years (mean 64.5 years, \pm SD 12.2). The weight of patients ranged from 50 to $120 \mathrm{~kg}$ (mean 76.2, \pm SD 15.7). Ideal body weight was used in obese patients. In the study 
population $60.4 \%$ had $\mathrm{CHF}$, the remainder (39.6\%) had AF.

\subsection{Data Collection}

Data was collected for each patient using their medical records, direct measurements, personal interview and blood sampling.

\subsection{Blood Samples Collection}

Blood samples for measurement of digoxin were drawn once steady-state concentrations of digoxin had been reached. Serum creatinine and potassium levels were also measured.

\subsection{Sample Schedule for Digoxin}

Fifty three patients participated in this study. One to three samples were taken from each patient, 3 samples were from 3 patients, 2 samples from 34 patients, and 1 sample from 16 patients. Samples were scheduled to be taken from each patient at the following times: a trough sample just before the first dose of the day; at 6- $8 \mathrm{~h}$ to coincide with the peak concentration; anytime post dose excluding peak and pre-dose.

\subsection{Digoxin Measurement}

Digoxin blood samples were analyzed by the AxSYM, it is an immunochemical automated analyzer made by Abbott Laboratories. The AxSYM digoxin II assay was a Microparticle Enzyme Immunoassay (MEIA) for the quantitative measurement of digoxin, a cardiovascular drug, in serum or plasma. The measurements obtained were used in the treatment of digoxin overdose and in monitoring levels of digoxin to ensure appropriate therapy.

\subsection{Potassium Measurement}

The ISE (Ion Selective Electrode) module provided the system with an electronic method for assaying $\mathrm{Na}, \mathrm{K}$, and chloride samples. Each ISE module could process up to 900 tests per hour. The ion selective electrodes were color-coded, modular plug-in cartridges.

\subsection{Serum Creatinine Measurement}

Creatinine was assayed using the method of Jaffe. Kinetic calorimetric assay was the basis of this test. The reaction was started after the addition of sodium hydroxide and picric acid to the sample. In alkaline solution, creatinine formed a yellow-orange complex with picrate. The color intensity was directly proportional to the creatinine concentration and could be measured photometrically. The assays used rate-blanking to minimize interference by bilirubin.

\section{Data Analysis}

\subsection{Pharmacokinetic Analysis}

The following pharmacokinetic parameters of digoxin were calculated:
A) Calculation of Creatinine clearance : CockcroftGault equations $1 \& 2$ used to calculate creatinine clearance [23].

\begin{tabular}{|c|c|}
\hline $\mathrm{Eq} \#$ & Equation used \\
\hline 1 & Cr.CL $=[(140-$ age $) * \mathrm{Wt}] /(72 * \mathrm{Scr})$ for male \\
\hline 2 & Cr.CL $=\left[(140-\right.$ age $\left.) * \mathrm{Wt}^{*} 0.85\right] /(72 * \mathrm{Scr})$ for female \\
\hline 3 & $\mathrm{CL}_{\mathrm{dig}}=0.33^{*} \mathrm{Wt}+0.9^{*} \mathrm{Cr} . \mathrm{CL}$ (for male) \\
\hline 4 & $\mathrm{CL}_{\mathrm{dig}}=0.8 * \mathrm{Wt}+\mathrm{Cr} . \mathrm{CL}$ (for female) \\
\hline 5 & $\mathrm{Cs}^{\mathrm{ss}}=\mathrm{F}(\mathrm{D} / \tau) / \mathrm{CL}_{\mathrm{dig}}$ \\
\hline 6 & $\mathrm{CL}_{\text {dig }}^{\mathrm{act}}=[\mathrm{F}(\mathrm{D} / \tau)] / \mathrm{C}_{\mathrm{avg}}^{\mathrm{ss}}$ \\
\hline 7 & $\mathrm{Vd}_{\mathrm{dig}}=(3.8 \mathrm{~L} / \mathrm{Kg})^{*} \mathrm{Wt}+(3.1)^{*} \mathrm{Cr} . \mathrm{CL}$ \\
\hline 8 & $\mathrm{Kel}=\mathrm{CL}_{\mathrm{dig}} / \mathrm{Vd} \mathrm{dig}_{\mathrm{dig}}$ \\
\hline 9 & $\mathrm{t}_{1 / 2}=0.693 / \mathrm{Kel}$ \\
\hline 10 & $\mathrm{D}=\mathrm{Cs}^{\mathrm{ss}} * \mathrm{CL}^{\mathrm{act}}{ }_{\mathrm{dig}} * \tau / \mathrm{F}$ \\
\hline
\end{tabular}

Where Cr.CL is creatinine clearance in $\mathrm{ml} / \mathrm{min}$, age in year, BW is the actual body weight or ideal body weight for obese patients (BMI>30) in $\mathrm{kg}$, Scr is serum creatinine in $\mathrm{mg} / \mathrm{dl}$.

B) Calculation of Predicted digoxin clearance : To estimate digoxin clearance for patients enrolled in this study used equations $3 \& 4$ [24], where $\mathrm{CL}_{\mathrm{dig}}$ is digoxin clearance in $\mathrm{ml} / \mathrm{min}$.

C) Calculation of predicted $\mathrm{Cs}^{\mathrm{ss}}$ : Predicated $\mathrm{Cs}^{\mathrm{ss}}$ of digoxin for patients in this study was calculated according to equation 5 [25], where $\mathrm{Cs}^{\mathrm{ss}}$ is the predicated serum digoxin concentration in $\mathrm{ng} / \mathrm{ml}, \mathrm{D}$ is maintenance dose of digoxin in $\mathrm{ng}, \tau$ is the dosage interval $1440 \mathrm{~min}, \mathrm{~F}$ is the bioavailability factor 0.7 for tablet, and $\mathrm{CL}_{\mathrm{dig}}$ is digoxin clearance in $\mathrm{ml} / \mathrm{min}$.

D) Calculation of actual digoxin clearance: Actual digoxin clearance was calculated based on equation 6 [25], where $\mathrm{CL}^{\mathrm{act}}$ dig is actual digoxin clearance in $\mathrm{ml} / \mathrm{min}$, $\mathrm{F}$ is bioavailability $0.7, \mathrm{D}$ is maintenance dose of digoxin, $\tau$ is the dose interval $1440 \mathrm{~min}, \mathrm{C}^{\mathrm{ss}}{ }_{\text {avg. }}=(\mathrm{C} 1+\mathrm{C} 2+\mathrm{C} 3 / 3)$ which is the average steady-state digoxin concentration.

E) Volume of distribution calculation: Volume of distribution of digoxin was calculated based on equation 7 [2], where $\mathrm{Vd}_{\text {dig }}$ is volume of distribution of digoxin in $\mathrm{L}$, $\mathrm{Wt}$ is weight in $\mathrm{kg}$, and $\mathrm{Cr}$.CL in $\mathrm{ml} / \mathrm{min}$.

F) Calculation of elimination rate constant: Equation 8 was used to calculate Kel [25], where Kel is the digoxin elimination rate constant (day'), $\mathrm{CL}_{\text {dig }}^{\text {act }}$ is actual digoxin clearance in $\mathrm{L} /$ day, $\mathrm{Vd} \mathrm{dig}_{\mathrm{g}}$ is volume of distribution of digoxin In L.

G) Calculation of $t_{1 / 2}$ : Equation 9 was used to calculate $t_{1 / 2}$ [25], where $t_{1 / 2}$ is the half -life of digoxin in day, Kel is the digoxin elimination rate constant.

H) Calculation of dose adjustment: Equation 10 was used to calculate dose adjustment, where $\mathrm{D}$ is dose adjustment in $\mathrm{mg}, \mathrm{Cs}^{\mathrm{ss}}=$ is the average steady state digoxin level according to the therapeutic range (1 for $\mathrm{CHF}, 1.5$ for AF), $\mathrm{CL}^{\mathrm{act}}$ dig is actual digoxin clearance, $\tau$ is dosage interval, $\mathrm{F}$ is the bioavailability factor 0.7 for digoxin tablet.

\subsection{Statistical Analysis}

Microsoft Excel program was used for descriptive statistics and t-testing. Individual data for each patient (age, sex, weight, dose, disease state, dose, $\tau$, serum creatinine, $\mathrm{C}_{\text {avg. }}^{\mathrm{ss}}$, and $\mathrm{F}$ ) and the appropriate equation for each pharmacokinetic parameter was entered to the excel 
program. Statistica program V4.5 was used for normality testing. Logarithmic transformation was used to ensure data normality.

\subsection{Population Pharmacokinetic Analysis}

Population Pharmacokinetic program used is NONMEM ADVAN 4 model. The final model was run without interaction as its inclusion invariably lead to underestimation of the observed values. Both 1 and 2 compartment models were investigated, but the latter model gave the better fit. The number of samples available was a limitation of the dataset; ideally 3 samples would be available for each patient. In the current dataset most subjects had 2 available concentrations although some only had 1. Attempts were made to fit all parameters (thetas and etas) together but invariably although the model reached completion the covariance step was aborted that can be due to the huge etas that were being estimated for Q and sometimes VT. In the final model, to allow completion of the covariance step, the intercompartmental clearance (Q) value was fixed based on literature data (taken from Hornestam et al, [26]). Using this approach, the fit of observed versus individual predicted plasma concentrations was reasonable.

\section{Results and Discussion}

\subsection{Serum Level of Potassium and Creatinine}

The result showed that the range of patient serum potassium was (3.2-5.4mmol/1), with a mean of $4.34 \mathrm{mmol} / 1.9 .5 \%$ of patients with potassium level out of the normal range ( 3 patients above the normal range and 2 patients below). However, the range of creatinine serum level for female patients between $(0.34-2.23 \mathrm{mg} / \mathrm{dl})$, with $51.7 \%$ of female patients out of normal range. The range of creatinine serum level for male patients between (0.36$1.95 \mathrm{mg} / \mathrm{dl}$ ), with $45.8 \%$ of male patients out of normal range.

\subsection{Blood Pressure and Heart Rate Measurement}

The American Heart Association and the Joint National Commission on Hypertension recommend that everyone should ideally have a blood pressure less than 120/80. Blood pressure between 120-140/80-90 is considered as pre hypertension. Blood pressure over 140/90 is considered as hypertension [27]. $18.8 \%$ of patients had hypertension, $37.7 \%$ had pre hypertension. The normal range of heart rate at rest is $60-100 \mathrm{bpm}$ [28]. Values for heart rate were outside the normal range in $7.5 \%$ of the study population.

\subsection{Serum Digoxin Concentrations}

The average serum digoxin levels in the fifty three patients involved in this study ranged from 0.11 to $4 \mathrm{ng} / \mathrm{ml}$ with a mean level of $0.89 \pm 0.72 \mathrm{ng} / \mathrm{ml}(\mathrm{CV}: 80.07 \%)$.

Twenty four males and twenty nine females participated in this study, there was no significant difference in mean serum digoxin level between male and female $\quad 1.07 \pm 0.92 \mathrm{ng} / \mathrm{ml}, \quad 0.75 \pm 0.45 \mathrm{ng} / \mathrm{ml}$ respectively, $\mathrm{P}=0.11$ as shown in Table 2 .

Table 2. Serum digoxin level in male and female patients

\begin{tabular}{|c|c|c|c|c|}
\hline Sex & $\% *$ & $\begin{array}{c}(\text { Mean } \pm \text { SD }) \\
\mathrm{ng} / \mathrm{ml}\end{array}$ & $\begin{array}{c}\text { Range } \\
(\mathrm{ng} / \mathrm{ml})\end{array}$ & P value \\
\hline Male & 45.28 & $1.07 \pm 0.92$ & $0.17-4.00$ & \multirow{2}{*}{0.11} \\
\hline Female & 54.72 & $0.75 \pm 0.45$ & $0.11-1.97$ & \\
\hline
\end{tabular}

*Percent of male and female

Serum digoxin levels were out of therapeutic range in $53.12 \%$ of patients with CHF and $42.85 \%$ in those with $\mathrm{AF}$ as shown in Table 3.

Table 3. Classification of patients with CHF, AF based on recommended therapeutic range $0.5-1.5,0.8-2 \mathrm{ng} / \mathrm{ml}$ respectively

\begin{tabular}{|c|c|c|c|}
\hline $\begin{array}{c}\text { Serum digoxin } \\
\text { range }\end{array}$ & $\begin{array}{c}\text { No. of } \\
\text { patient }\end{array}$ & $\%$ & $\begin{array}{c}\text { Mean of Cpavg } \pm \text { SD } \\
(\mathrm{ng} / \mathrm{ml})\end{array}$ \\
\hline Sub-therapeutic & 12,12 & 37,57 & $\begin{array}{c}0.325 \pm 0.124, \\
1.134 \pm 0.33\end{array}$ \\
\hline Therapeutic & 15,9 & 47,43 & $\begin{array}{c}0.813 \pm 0.223, \\
0.549 \pm 0.137\end{array}$ \\
\hline Toxic & 5,0 & 16,0 & $2.623 \pm 0.936,-$ \\
\hline
\end{tabular}

Predicted serum digoxin concentration was calculated and compared with observed (actual) serum digoxin concentration, no correlation was found between in the two values, Figure 1.

\subsection{Creatinine Clearance, Predicted Digoxin Clearance, and Volume of Distribution of Digoxin.}

Creatinine clearance level for the patients participated in this study was ranged from 18.76-211.46 $\mathrm{ml} / \mathrm{min}$. The data showed that the estimated digoxin clearance ranged from $37.35-240.40 \mathrm{ml} / \mathrm{min}(120.29 \pm 46.68 \mathrm{ml} / \mathrm{min})$. A linear relationship exists between renal clearance of digoxin and creatinine clearance as shown in Figure 2.

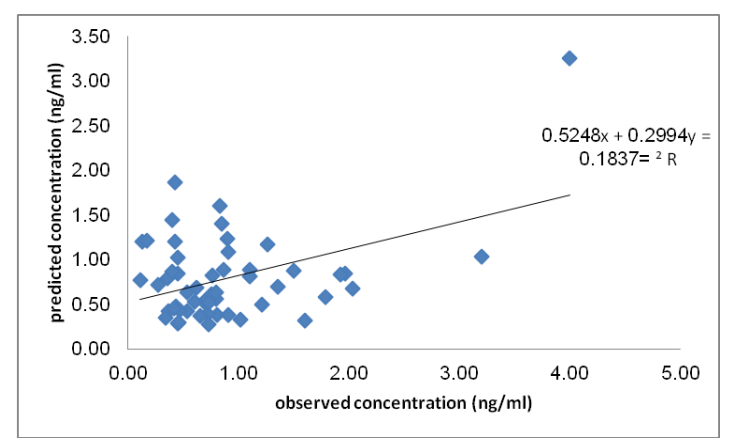

Figure 1. Observed versus predicted serum digoxin concentrations

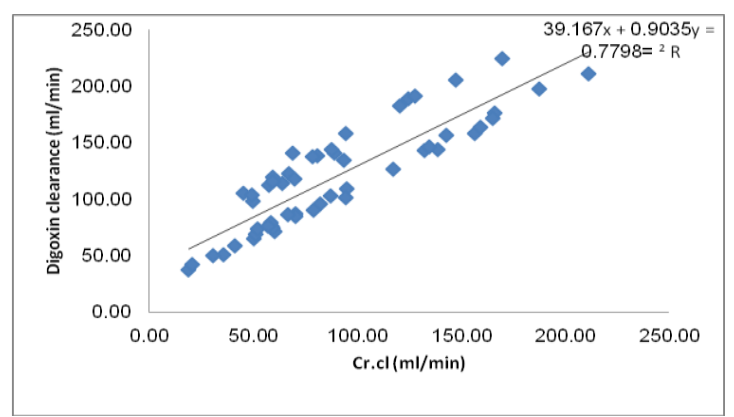

Figure 2. Relationship between digoxin clearance and creatinine clearance 
The estimated volume of distribution of digoxin was ranged from 293.77 to $912.54 \mathrm{~L}$. The mean volume of distribution of digoxin was $541.57 \mathrm{~L}(7.73 \mathrm{~L} / \mathrm{Kg})$ which is within the reported volume of distribution of digoxin $(7.3 \mathrm{~L} / \mathrm{kg})$ in patients with normal renal function.

\subsection{Actual clearance, Kel and $t_{1 / 2}$ of Digoxin}

Actual digoxin clearance for patients enrolled in this study ranged from 27.34-795.45L/day (200.57士 154.5216L/day). Actual digoxin clearance was examined and compared with estimated digoxin clearance, according to this comparison no correlation was found between them.

Actual digoxin clearance was inversely related to the half life, though around 400, the half-life appeared to reach a plateau, Figure 3 .

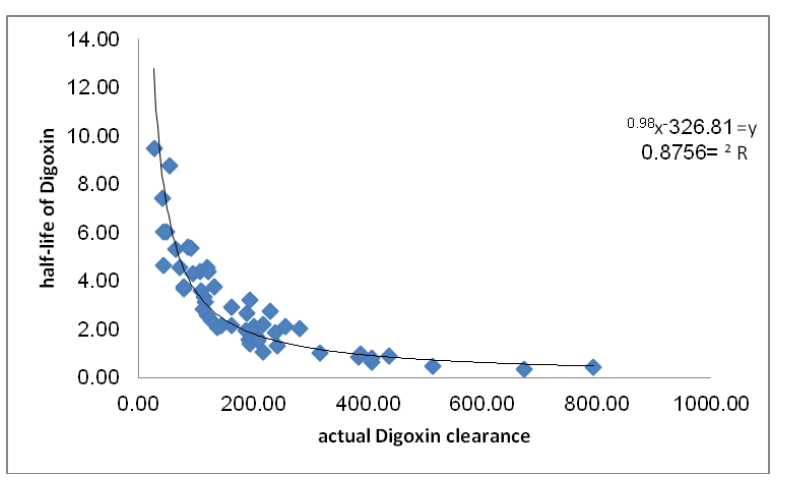

Figure 3. Correlation between actual digoxin clearance and half-life

\subsection{Digoxin Dose Adjustment}

Study results that $49.05 \%$ of patients had digoxin serum concentrations outside of the therapeutic range. For each patient that was out of therapeutic range, a dose adjustment was recommended based in the measured digoxin level (eq. 10). There are many factors may affect serum digoxin level, these include: age, gender, diseases conditions (renal dysfunction, heart failure, and thyroid disease), drug-drug interaction, and tissue response. A decision to make dose adjustment, therefore took these individual patient factors into account.

\subsubsection{Dose Adjustment for Patients with CHF}

Digoxin dose adjustment for those patients with CHF that their serum digoxin level out of therapeutic range presented in Table 4 . Patient number 5 and 6 are already on $0.25 \mathrm{mg}$ of digoxin dose, however the dose adjustment calculated for these patients (eq 10) is $0.58 \mathrm{mg}$ which higher than the recommended digoxin dose. From reviewing all data that collected from medical files and from interviews with these patients, the factors that affected plasma digoxin level were not noticed. Therefore, a second digoxin level measurement is recommended before any dose adjustment.

Based on patient interviewing patient number 9 and 43, they admitted that they were not taking digoxin dose regularly as prescribed (missing dose). This non compliance patients can be helped by advising them committed to the time and maintenance on the dose that prescribed without any dose adjustment. Patients 13 and 19 were on $0.125 \mathrm{mg}$ digoxin dose and their average digoxin level is $0.44 \mathrm{ng} / \mathrm{ml}$ and $0.37 \mathrm{ng} / \mathrm{ml}$ respectively. Dose adjustment were calculated for patients 13 and 19 (eq 10) and found to be $0.29 \mathrm{mg} 0.3 \mathrm{mg}$ respectively. Therefore, the new recommended digoxin dose for those patients is $0.25 \mathrm{mg}$ which may maintain their digoxin level with therapeutic range. Serum digoxin level in Patient 21 was $1.97 \mathrm{mg}$ which is above therapeutic range. The possible explanation for the high serum digoxin level is that the patient also taking Bisoprolol (concor ${ }^{\mathrm{R}} 5 \mathrm{mg}$ ) which may enhanced absorption as well as reduced renal excretion of digoxin due to inhibition of intestinal and renal P-glycoprotein efflux transporter. Therefore no dose adjustment recommended before discussion this point with the physician.

Digoxin level of patients number 31 and 37 were $0.34 \mathrm{ng} / \mathrm{ml}$ and $0.36 \mathrm{ng} / \mathrm{ml}$ respectively, both patients were on $0.125 \mathrm{mg}$ of digoxin. The data collected from interviews and medical files indicated that these patients have no drug-drug interaction or any disease state that affected the digoxin level, but single digoxin level for these patients was measured. Therefore these patients need further follow up, or increased the digoxin dose to $0.25 \mathrm{mg}$. Digoxin level of patient number 38 was $1.92 \mathrm{ng} / \mathrm{ml}$ which is above the therapeutic range, medical file for this patient indicated that this patient suffered from alcoholic liver cirrhosis. Liver responsible for metabolize $26 \%$ of digoxin dose, so accumulation of digoxin may be occurred and lead to elevate the digoxin dose. Because the dose adjustment for this patient was $0.13 \mathrm{mg}$ while the dose taken was 0.25 .Therefore, either keep the patient on the same dose $(0.25 \mathrm{mg})$ digoxin but given every other day, or reduce the dose to $0.125 \mathrm{mg}$ of digoxin daily.

The digoxin level in patient number 42,45 , is 0.45 , $3.2 \mathrm{ng} / \mathrm{ml}$, which is out of therapeutic range. The main reason was due to error in the time of taking blood sample. Therefore, no dose adjustment needed at this time and further blood sample should be taken at appropriate time is recommended. Patient number 43 had digoxin level of $4 \mathrm{ng} / \mathrm{ml}$. This result was due to patient incompliance (patient was taken double dose of digoxin). Therefore digoxin dose was stopped for two days, and then returned to maintenance digoxin dose of $0.25 \mathrm{mg}$.

Digoxin level of patient number 44 was $0.44 \mathrm{ng} / \mathrm{ml}$ and received digoxin dose of $0.125 \mathrm{mg}$. The dose adjustment calculated was $0.31 \mathrm{mg}$ (eq 10), therefore, a dose of $0.25 \mathrm{mg}$ of digoxin was recommended.

Patient number 47 was on $0.125 \mathrm{mg}$ daily dose of digoxin and his average digoxin level was $0.13 \mathrm{ng} / \mathrm{ml}$ (below therapeutic range). Based on medical file, this patient appeared that he was used ventolin (albuterol). This drug decreased the level of digoxin in blood, so this reason may be interpreted why the digoxin level of this patient resulted below the therapeutic range.

Serum digoxin level of patient 49 was $2.03 \mathrm{ng} / \mathrm{ml}$ which is above the recommended therapeutic range. The sample of digoxin was tacking in a wrong time through distribution phase (after 2 hours of last dose). Therefore this patient was not required dose adjustment, but only should be repeated the measurement of digoxin at the true time.

Patients number 50 and 51 had plasma level below the therapeutic range $(0.11 \mathrm{ng} / \mathrm{ml}$ and $0.17 \mathrm{ng} / \mathrm{ml}$ respectively). Who were on $0.125 \mathrm{mg}$ daily dose of digoxin, but single digoxin level for those patients was measured. Therefore these patients need further follow up, or increased the digoxin dose to $0.25 \mathrm{mg}$. 
Table 4. Dose adjustment for digoxin in patients with CHF based on equation 10

\begin{tabular}{|c|c|c|c|c|}
\hline $\begin{array}{c}\text { Dose adjustment } \\
(\mathrm{mg})\end{array}$ & Dose(mg) & $\begin{array}{c}\text { Therapeutic } \\
\text { range }(0.5-1.5) \\
\text { ng/ml }\end{array}$ & $\begin{array}{c}\text { Cs }{ }^{\text {avg }} \text { digoxin } \\
(\mathrm{ng} / \mathrm{ml})\end{array}$ & Patient \# \\
\hline 0.58 & 0.25 & Below & 0.43 & 5 \\
\hline 0.58 & 0.25 & Below & 0.43 & 6 \\
\hline noncompliance & 0.125 & Below & 0.28 & 9 \\
\hline 0.29 & 0.125 & Below & 0.44 & 13 \\
\hline 0.3 & 0.125 & Below & 0.37 & 19 \\
\hline Drug interaction & 0.125 & Above & 1.97 & 21 \\
\hline 0.37 & 0.125 & Below & 0.34 & 31 \\
\hline 0.35 & 0.125 & Below & 0.36 & 37 \\
\hline 0.13 & 0.25 & Above & 1.92 & 38 \\
\hline Sample time error & 0.125 & Below & 0.45 & 42 \\
\hline noncompliance & 0.25 & Above & 4.00 & 43 \\
\hline 0.31 & 0.125 & Below & 0.40 & 44 \\
\hline Sample time error & 0.125 & Above & 3.20 & 45 \\
\hline Drug interaction & 0.125 & Below & 0.13 & 47 \\
\hline Sample time error & 0.125 & Above & 2.03 & 49 \\
\hline Single measurement & 0.125 & Below & 0.11 & 50 \\
\hline Single measurement & 0.125 & Below & 0.17 & 51 \\
\hline
\end{tabular}

\subsubsection{Dose Adjustment for Patients with AF}

Digoxin dose adjustment for those patients with $\mathrm{AF}$ that their serum digoxin level out of therapeutic range presented in Table 5. Digoxin dose for patient number 8 , 26, 32, 34 may need to increased to $0.25 \mathrm{mg}$ daily (eq. 10 ). Patient number 18, 35, 40, dose adjustment calculated based on eq. 10 is $0.4,0.44$, and 0.41 respectively which is higher than the recommended dose of oral digoxin. Therefore another digoxin level measurement is recommended in addition to extensive reviewing of their medical files. Patient number 25 had hypothyroidism in addition to atrial fibrillation. It has been reported that patient with hypothyroid state, the sensitivity to digoxin effect may be increased due to change in clearance of digoxin [29] and low dose of digoxin is recommended. When euthyroid state achieved, the dose of digoxin should increased [30]. Therefore, the dose in this patient was increased to $0.25 \mathrm{mg}$ instead of $0.125 \mathrm{mg}$.

Patient number 39 was taking $0.25 \mathrm{mg}$ of digoxin daily, serum digoxin level for this patient below the therapeutic range $(0.4 \mathrm{ng} / \mathrm{ml})$. This patient was suffered from breast cancer and she was on chemotherapy treatment. There is drug- drug interaction between chemotherapy drug and digoxin. Chemotherapy drug decreases the concentration of digoxin, the mechanism though to be responsible for this interaction is the transient damage to the intestinal mucosa caused by cancer chemotherapy [31]. Therefore before any dose adjustment, the digoxin should be given either one hour before or two hours after chemothepy agent and then measured digoxin level.

\subsection{Correlation and Regression Analysis}

There was no correlation between age and log dose normalized. This result corresponds with previous studies. Ferrari et al remarked that there was no concurrence between age and digoxin serum level [32], while Rich et al noticed that the mean digoxin levels tended to be higher in older patients despite an age related decline in mean dosage [33]. Creatinine clearance was not correlated to the $\log$ dose normalized, similar to the findings of the work by
Baylis [34]. A correlation could not be found between log dose normalized and observed volume of distribution of digoxin and BMI respectively. For patients with a BMI greater than $40 \%$, ideal body weight was used rather than actual BMI. These principles are consistent with the data recorded by Abernethy, whose work indicated that for obese patients loading and maintenance doses of digoxin should be determined on the basis of IBW rather than TBW [35]. Weight has no correlation to the log dose normalized. Potassium was not correlated to $\log$ dose normalized a result supported by literature studies. Ferrari et al [32]. It has been reported that hypokalemia is the most important and frequent factor causing increased sensitivity of the tissues to digoxin [36]. The effect is independent of digoxin plasma concentration. So according to this notion and the measured normal $\mathrm{K}$ levels, we cannot see any correlation between potassium concentration and digoxin serum level in this study. For the cardiovascular measures: systolic blood pressure, diastolic blood pressure and heart rate, there was has no correlation to the log dose normalized.

Table 5. Dose adjustment for digoxin in patients with AF based on equation 10

\begin{tabular}{|c|c|c|c|c|}
\hline $\begin{array}{c}\text { dose } \\
\text { adjustment } \\
(\mathrm{mg})\end{array}$ & $\begin{array}{c}\text { Dose } \\
(\mathrm{mg})\end{array}$ & $\begin{array}{c}\text { Therapeutic } \\
\text { Range } \\
(0.8-2) \mathrm{ng} / \mathrm{ml}\end{array}$ & $\begin{array}{c}\mathrm{Cs}^{\text {ssavg }} \\
(\mathrm{ng} / \mathrm{ml})\end{array}$ & Patient \# \\
\hline 0.26 & 0.125 & below & 0.73 & 8 \\
\hline 0.40 & 0.125 & below & 0.47 & 18 \\
\hline 0.45 & 0.125 & below & 0.42 & 25 \\
\hline 0.27 & 0.125 & below & 0.69 & 26 \\
\hline 0.26 & 0.125 & below & 0.73 & 32 \\
\hline 0.31 & 0.125 & below & 0.61 & 34 \\
\hline 0.44 & 0.25 & below & 0.45 & 35 \\
\hline 0.50 & 0.25 & below & 0.4 & 39 \\
\hline 0.41 & 0.125 & below & 0.46 & 40 \\
\hline
\end{tabular}

However, a strong relationship between actual digoxin clearance and $\log$ dose normalized $\left(\mathrm{R}^{2}=0.999\right)$. Since actual digoxin clearance is proportionally to daily dose and irreversibly to serum level of digoxin (eq 6). The mainly dose prescribed for all patients enrolled in this study were either $0.125 \mathrm{mg}$ or $0.25 \mathrm{mg}$. Therefore, the variation in serum level of digoxin play important role in actual digoxin clearance. Also, strong correlation was found between $t 1 / 2$ and $\log$ dose normalized. $t 1 / 2$ has strong reverse correlation to the actual digoxin clearance (eq 9). Actual digoxin clearance and log dose normalize proportional reversely, so the $t 1 / 2$ of digoxin is correlate proportionally with log dose normalize. Correlation analysis results were in agreement with regression analysis results as shown in Table 6.

Table 6. Analysis of variance of Log Dose Normalized Css ${ }^{\text {avg }}$

\begin{tabular}{|c|c|c|c|c|c|}
\hline P-value & F-ratio & MS & DF & SS & Source \\
\hline 0.858 & 0.033 & 0.00 & 1 & 0.00 & VD \\
\hline 0.00 & 226.382 & 2.989 & 1 & 2.989 & Cl. Digoxin \\
\hline 0.858 & 0.032 & 0.00 & 1 & 0.00 & CL.CR \\
\hline 0.62 & 0.25 & 0.003 & 1 & 0.003 & Sex \\
\hline 0.343 & 0.924 & 0.012 & 1 & 0.012 & Disease \\
\hline 0.15 & 2.116 & 0.029 & 1 & 0.029 & Bp sys \\
\hline 0.711 & 0.14 & 0.002 & 1 & 0.002 & BpDIAS \\
\hline 0.579 & 0.313 & 0.004 & 1 & 0.004 & H.R. \\
\hline 0.856 & 0.033 & 0 & 1 & 0 & Age \\
\hline 0.858 & 0.032 & 0 & 1 & 0 & Wt. \\
\hline
\end{tabular}




\subsection{Pharmacokinetic Parameters of Digoxin}

The pharmacokinetics parameters of digoxin according to traditional methods obtained in this study represented in the Table 7.

Table 7. Pharmacokinetic parameters of digoxin

\begin{tabular}{|c|c|c|c|}
\hline CV\% & SD & Mean & Pharmacokinetic parameters \\
\hline 50.80687 & 45.61764 & 89.78636 & Cr.CL(ml/min) \\
\hline 77.0418 & 154.52 & 200.57 & dig.CL.act.(L/day) \\
\hline 27.6739 & 149.8736 & 541.5702 & ${ }^{*} \mathrm{Vd}(\mathrm{L})$ \\
\hline 68.95 & 2.05 & 2.98 & $\mathrm{t} 1 / 2$ (day) \\
\hline
\end{tabular}

Population pharmacokinetic analysis of digoxin data from Jordanian patients enrolled in this study and other studies are presented in Table 8. Good agreement between observed and individually predicted concentration values Figure 4.

Table 8. Population pharmacokinetic of digoxin from different studies

\begin{tabular}{|c|c|c|c|c|c|}
\hline $\begin{array}{c}\text { Present } \\
\text { study }\end{array}$ & $\begin{array}{c}\text { Zhou et } \\
\text { al }\end{array}$ & $\begin{array}{c}\text { Desoky et } \\
\text { al }\end{array}$ & $\begin{array}{c}\text { Yukawa et } \\
\text { al }\end{array}$ & $\begin{array}{c}\text { Hornestam et } \\
\text { al }\end{array}$ & Parameters \\
\hline $3.34 \mathrm{~L} / \mathrm{h}$ & $4.88 \mathrm{~L} / \mathrm{hr}$ & $0.38 \mathrm{~L} / \mathrm{h} / \mathrm{kg}$ & & $9.88 \mathrm{~L} / \mathrm{hr}$ & $\mathrm{CL}$ \\
\hline $3.27 \mathrm{~L}$ & & $1.38 \mathrm{~L} / \mathrm{kg}$ & $1.83 \mathrm{~L} / \mathrm{kg}$ & $27.8 \mathrm{~L}$ & $\mathrm{Vc}$ \\
\hline $123 \mathrm{~L}$ & & $9.11 \mathrm{~L} / \mathrm{kg}$ & $22.6 \mathrm{~L} / \mathrm{kg}$ & $444 \mathrm{~L}$ & $\mathrm{Vt}$ \\
\hline $72 \mathrm{~L} / \mathrm{h}$ & & $0.47 \mathrm{~L} / \mathrm{h} / \mathrm{kg}$ & $0.629 \mathrm{~L} / \mathrm{h} / \mathrm{kg}$ & $71.8 \mathrm{~L}$ & $\mathrm{Q}$ \\
\hline $1.25 \mathrm{~L} / \mathrm{h}$ & $1.63 \mathrm{~L} / \mathrm{h}$ & & & & $\mathrm{KA}$ \\
\hline
\end{tabular}

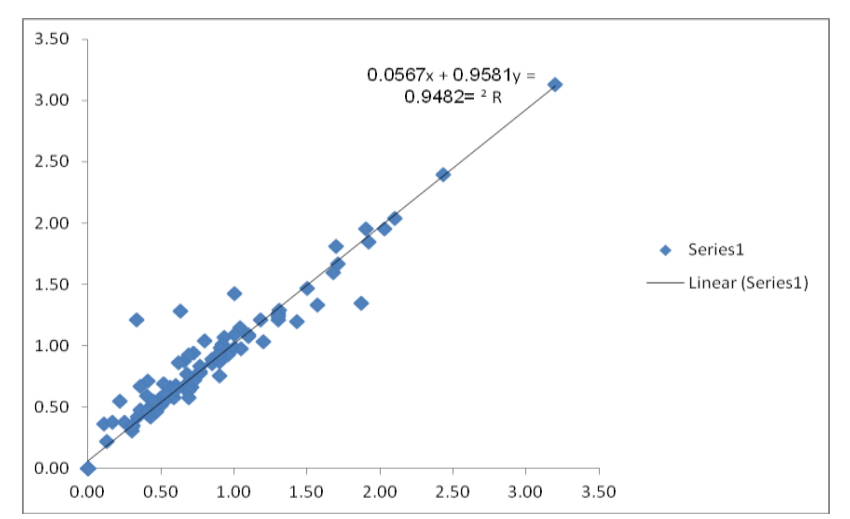

Figure 4. Observed concentration versus individually predicted concentration

\section{Conclusions}

Based on the results of this investigation which revealed that around $50 \%$ of patients with $\mathrm{CHF}$ or AF had their serum digoxin level out of therapeutic range. In addition, the data also showed high interindividual variability in pharmacokinetic parameters of digoxin. Therefore, therapeutic drug monitoring of digoxin among those patient populations is necessary to optimize digoxin therapy. Digoxin pharmacokinetics was shown similar to those reported in non-Jordanian patients; and the calculated population pharmacokinetic parameters were also in agreement with literature values.

\section{Acknowledgments}

NONMEM programme was kindly provided by $\mathrm{Dr}$ Hussain Mulla of University Hospitals of Leicester Glenfield Hospital, Dept of Pharmacy, Leicester, UK.
This work is submitted in partial fulfillment of master degree in Pharmaceutical Sciences at college of Pharmacy, Petra University, Amman, Jordan.

\section{References}

[1] Figueiredo, E.L., Machado, F.P. Digoxin's roles in heart failure patients: An overview. Cardiology. 5 (5): 59-64, 2010.

[2] Winter, M.L. Basic clinical pharmacokinetics. Philadelphia, Lippincott Williams \& Wilkins, 2004.

[3] DiPiro J.T et al. Pharmacotherapy A pathophysiologic approach, seven edition McGraw HILL, 2008.

[4] Duhme D.W.,, Greenblatt D. J., Koch-Weser J. Reduction of digoxin toxicity associated with measurement of serum levels. A report from the Boston Collaborate Drug Surveillance Program. Ann Inter Med, 80: 516-519, 1974.

[5] Dobbs R.J., Nicholson P.W., Dobbs S.M., O'Neill C.J. Therapeutic drug monitoring of digoxin: Helper or hinders? Eur. J. clin. Pharmacol. 31:491-5, 1986.

[6] Sidwell A., Barclay M., Begg E., Moore G. Digoxin therapeutic monitoring: an audit and review. The New Zeland Medical Journal, 116 (1187):1-6, 2003.

[7] Farid S. F, Abbassia M.M, Sabrya N.A., Abdl Elkhaeq. Evaluation of digoxin in two Egyptian hospitals A pilot study. Austaralian Journal of basic and applied Sciences, 3(3):1838-1841, 2009.

[8] Aronson J.K, Hardman M. ABC of monitoring drug therapy. Digoxin. BMJ, 305: 1149-52, 1992.

[9] Kumana CR, Chan YM, Kou M. Audit exposes flawed blood sampling for "digoxin levels". Ther Drug Monit, 14: 155-8, 1992.

[10] Williamson KM, Thrasher KA, Fulton KB, et al. Digoxin toxicity: an evaluation in current clinical practice. Arch Intern Med, 158: 2444-9, 1998

[11] Smith TW, Haber E. Digoxin intoxication: the relationship of clinical presentation to serum digoxin concentration. J Clin Invest, 49: 2377-86, 1970.

[12] Canas F, Tanasijevic MJ, Ma'luf N, Bates DW. Evaluating the appropriateness of digoxin level monitoring. Arch Intern Med, 159: 363-8, 1999.

[13] Copeland RJ, Thorpe H, Kay EA. Inappropriate digoxin monitoring.J Clin Pharm Ther. 17:173-4, 1992.

[14] Slaughter RL, Schneider PJ, Visconti JA. Appropriateness of the use of serum digoxin and digitoxin assays. Am J Hosp Pharm, 35: 1376-9. 1978.

[15] Mordasini M.R., Krabenbublr S., Schlienger R. G. Appropriateness of digoxin level monitoring. SWISS MED WKLY, 132: 506-512, 2002.

[16] Orrico K. B., Wu. M., Wilson A. R. Assessment of the appropriateness of serum digoxin concentration measurement in a medical group setting. Journal of Managed Care Pharmacy, 17(9): 695-700.2011.

[17] Jessup M., Abraham WT., Casy DE, et al 2009 Focused Update: ACCF/AHA Guidelines for the Diagnosis and Management of Heart Failure in Adults A Report of the American College of Cardiology Foundation/American Heart Association Task Force on Practice Guidelines: Developed in Collaboration With the International Society for Heart and Lung Transplantation. Circulation, 119: 1977-2016. 2009.

[18] Nagaraja N.V, Park Y.J, Jeon S, Sands C.D, Derendorf H. Population pharmacokinetics of digoxin in Korean patients. Int $\mathrm{J}$ Clin Pharmacol Ther. 38(6):291-7, 2000.

[19] Zhou X.D, Gao Y, Guan Z, Li ZD, Li J. Population pharmacokinetic model of digoxin in older Chinese patients and its application in clinical practice. Acta Pharmacol Sin., 31(6):753$8,2010$.

[20] Xiao-dan Zhou, Yan Gao, Zheng Guan, Zhong-dong Li and Jun Li. Population pharmacokinetic model of digoxin in older Chinese patients and its application in clinical practice. Acta Pharmacologica Sinica, 31: 753-758. 2010.

[21] EL Desoky, E.S. Nagaraja, Nelamangala V.2; Derendorf, Hartmut. Population Pharmacokinetics of Digoxin in Egyptian Pediatric Patients: Impact of One Data Point Utilization. American Journal of Therapeutics: 9(6), 492-498. 2002.

[22] Yukawa, E., Suematu, F.; Yukawa, M., Minemoto, M., Ohdo, S., Higuchi, S., Goto, Y., Aoyama, T. Population Pharmacokinetics of 
Digoxin in Japanese Patients: A 2-Compartment Pharmacokinetic Model. Clinical Pharmacokinetics, 40 (10), 773-781. 2001.

[23] Cockcroft, D. \& Gault, M., Prediction of creatinine clearance from serum creatinine. Nephron. 16, 31-41. 1976.

[24] Ansel, H. \& Prince, S. Pharmaceutical calculations: the pharmacist's handbook. 1st Ed. United States of America: Lippincott Williams \& Wilkins, 2004.

[25] Bauer, L.A., Applied Clinical Pharmacokinetics. 1st Ed. United States of America: McGraw-Hill Professional. 2001.

[26] Hornestam, B. \& Karlsson, M., Intravenously administered digoxin in patients with acute atrial fibrillation: a population pharmacokinetic/pharmacodynamic analysis based on the Digitalis in Acute Atrial Fibrillation trial. Eur J Clin Pharmacol 58.P.PP. 747-755, 2003.

[27] Liu, D., Stay Healthy, Live Longer, Spend Wisely: Making Intelligent Choices inAmerica's Healthcare System. 1st Ed. United States of America: Stetho Publishing, 2008.

[28] Fong, B., Fong, A.C.M. \& Li, C.K., Telemedicine Technologies: Information Technologies in Medicine and Telehealth. 1st Ed. india: John Wiley and Sons, 2011.

[29] Goroll, A. \& Mulley, A., Primary Care Medicine: Office EvaluationAnd Management of The AdultPatient. 6th Ed. china: Lippincott Williams \& Wilkins. 2009.

[30] Ford, S.M. \& Roach, S.S., Roach's Introductory Clinical Pharmacology. 9th Ed. London: Lippincott Williams \& Wilkins. 2009.
[31] Burke, M., Wilkes, G. \& Ingwersen, K., Cancer Chemotherapy: a nursing process approach. 3rd Ed. United States of America: Jones \& Bartlett Learning, 2001.

[32] Ferrari, S.J., Bestetti, R.B., Cardinalli-neto, A. \& Bortoluzzi, T.B., Article / Artigo Digoxin serum levels in patients with Chagas cardiomyopathy and heart failure Níveis séricos de digoxina em pacientes com insuficiência cardíaca secundária à cardiomiopatia da doença de Chagas. Revista da Sociedade Brasileira de Medicina Tropical. 43 (5). 496-499. 2010.

[33] Rich, M.W., McSherry, F., Williford, W.O. \& Yusuf, S., Effect of age on mortality, hospitalizations and response to digoxin in patients with heart failure: the DIG study. Journal of the American College of Cardiology. 38 (3). 806-13. 2001.

[34] Baylis, E.M., Hall, M.S., Lewis, G. \& Marks, V., Effects of renal function on plasma digoxin levels in elderly ambulant patients in domiciliary practice. British medical journal. 1 (5796). 338-41. 1972.

[35] Abernethy, D., Greenblatt, D. \& Smith, T. (1981a). Digoxin disposition in obesity: Clinical pharmacokinetic investigation. American Heart Journal. 102, 740-744. 1981.

[36] Hosenpud, J.D. \& Greenberg, B.H., Congestive Heart Failure. 3rd Ed. United States of America: Lippincott Williams \& Wilkins, 2007. 